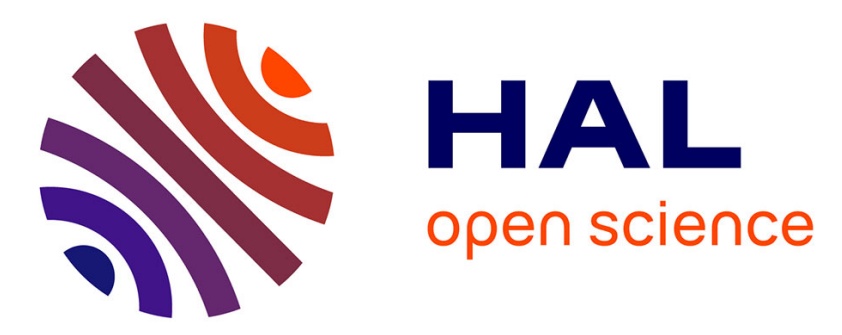

\title{
Crystal structure of a new ordered form of ammonium hydrogen succinate $\mathrm{NH} 4 \mathrm{HC} 4 \mathrm{H} 4 \mathrm{O} 4$
}

\author{
Pierric Lemoine, Noee Dumait, Vincent Dorcet, Stéphane Cordier
}

\section{To cite this version:}

Pierric Lemoine, Noee Dumait, Vincent Dorcet, Stéphane Cordier. Crystal structure of a new ordered form of ammonium hydrogen succinate NH4HC4H4O4. Journal of Chemical Crystallography, 2020, 50 (1), pp.35-40. 10.1007/s10870-018-0757-8 . hal-02127330

\section{HAL Id: hal-02127330 \\ https://hal-univ-rennes1.archives-ouvertes.fr/hal-02127330}

Submitted on 13 May 2019

HAL is a multi-disciplinary open access archive for the deposit and dissemination of scientific research documents, whether they are published or not. The documents may come from teaching and research institutions in France or abroad, or from public or private research centers.
L'archive ouverte pluridisciplinaire HAL, est destinée au dépôt et à la diffusion de documents scientifiques de niveau recherche, publiés ou non, émanant des établissements d'enseignement et de recherche français ou étrangers, des laboratoires publics ou privés. 


\title{
Crystal structure of a new ordered form of ammonium hydrogen succinate $\mathrm{NH}_{4} \mathrm{HC}_{4} \mathrm{H}_{4} \mathrm{O}_{4}$
}

\author{
Pierric Lemoine ${ }^{a, *}$, Noée Dumait ${ }^{a}$, Vincent Dorcet ${ }^{\mathrm{a}}$, Stéphane Cordier ${ }^{\mathrm{a}}$ \\ ${ }^{a}$ Univ Rennes, CNRS, ISCR-UMR 6226, F-35000 Rennes, France \\ *e-mail: pierric.lemoine@univ-rennes1.fr
}

\begin{abstract}
Triclinic ammonium hydrogen succinate compound (space group $P \overline{1}$ ) is known to present very short $\mathrm{O}-\mathrm{H} \cdots \mathrm{O}$ hydrogen bonds in association with a second-order phase transition around $170 \mathrm{~K}$. Whatever the temperature, its crystal structure is characterized by a statistical distribution of the hydrogen atom belonging to the hydrogen succinate molecule on two crystallographic sites, leading to a disordered structure. In this study, we report on the crystal structure of a new ordered structural form of the title compound $\mathrm{NH}_{4} \mathrm{HC}_{4} \mathrm{H}_{4} \mathrm{O}_{4}$, determined by single-crystal X-ray diffraction at room temperature. This new ordered form crystallizes in the triclinic space group $P \overline{1}$ with refined cell parameters: $a=6.4868(16) \AA, b=7.4313(17) \AA, c=7.4339(17) \AA, \alpha=112.058(8)^{\circ}$, $\beta=96.477(9)^{\circ}, \gamma=109.026(8)^{\circ}$ and $V=302.45(12) \AA^{3}$. Hydrogen succinate molecules are in trans conformation in the ordered form and in gauche conformation in the disordered one. It leads to different molecular assemblies of the ammonium cations and hydrogen succinate anions, and consequently, to different hydrogen bond networks. The crystal structure stability of this new ordered structural form is discussed and compared to that of the disordered form.
\end{abstract}

Keywords: Ammonium, Hydrogen succinate, Single-crystal X-ray diffraction, Hydrogen bond, Crystal structure

\section{INTRODUCTION}

Numerous molecular assemblies stabilized by the existence of very short $\mathrm{O}-\mathrm{H} \cdots \mathrm{O}$ hydrogen bonds are reported in acidic salts of succinic acid $\mathrm{MHC}_{4} \mathrm{H}_{4} \mathrm{O}_{4}$ family $\left(\mathrm{M}=\mathrm{Li}^{+}\right.$[1], $\mathrm{Na}^{+}$[2,3], $\mathrm{K}^{+}$[4], $\mathrm{Rb}^{+}$[2], $\mathrm{Cs}^{+}$[5], $\mathrm{NH}_{4}^{+}$[6-8], $\left\{\left(\mathrm{C}_{4} \mathrm{H}_{4}\right)\left(\mathrm{NH}_{3}{ }^{+}\right)_{2}\right\}_{1 / 2}$ [9], $\left(\mathrm{CH}_{3}\right) \mathrm{NH}_{3}{ }^{+}$[10], $\left(\mathrm{C}_{2} \mathrm{H}_{5}\right) \mathrm{NH}_{3}{ }^{+}$[11], $\left(\mathrm{C}_{3} \mathrm{H}_{5}\right) \mathrm{NH}_{3}{ }^{+}$[12], $\left(\mathrm{C}_{7} \mathrm{H}_{7} \mathrm{O}\right) \mathrm{NH}_{3}{ }^{+}$[13], $\left(\mathrm{C}_{8} \mathrm{H}_{15}\right) \mathrm{NH}_{3}{ }^{+}$ [14], $\left(\mathrm{C}_{17} \mathrm{H}_{22} \mathrm{NO}\right) \mathrm{NH}^{+}$[15], $\left(\mathrm{CH}_{3}\right)_{2} \mathrm{NH}_{2}^{+}$[10], $\left(\mathrm{C}_{2} \mathrm{H}_{5}\right)_{2} \mathrm{NH}_{2}{ }^{+}$[11], $\left(\mathrm{C}_{2} \mathrm{H}_{5} \mathrm{O}\right)_{3} \mathrm{NH}^{+}$[16,17], $\left(\mathrm{C}_{2} \mathrm{H}_{5}\right)_{4} \mathrm{~N}^{+}$[18]). Among these salts, the triclinic ammonium hydrogen succinate compound $\mathrm{NH}_{4} \mathrm{HC}_{4} \mathrm{H}_{4} \mathrm{O}_{4}$ evidences a second order phase transition around $170 \mathrm{~K}$ [6-8]. It was shown that this structural phase transition modifies the geometry of the hydrogen bonds between ammonium and hydrogen succinate ions, but is neither related to the loss of the center of symmetry or the formation of a superstructure, nor related to the breaking of hydrogen bonds or to the crystallographic reorganization of the hydrogen atom belonging to the carboxyl group $[7,8]$.

During investigations in water solution containing ammonium thiosulfate $\left(\mathrm{NH}_{4}\right)_{2} \mathrm{~S}_{2} \mathrm{O}_{3}$ and succinic acid $\mathrm{C}_{4} \mathrm{H}_{6} \mathrm{O}_{4}$, we obtained colorless single-crystals. Their analysis by $\mathrm{X}$-ray diffraction at room temperature indicates the crystallization of the title compound $\mathrm{NH}_{4} \mathrm{HC}_{4} \mathrm{H}_{4} \mathrm{O}_{4}$ in a new structural form also of triclinic symmetry. This new form, called ordered form, is characterized by the localization of hydrogen atom belonging to the carboxyl group on one crystallographic site, on the contrary to the other form, called disordered form, where this hydrogen atom is statistically distributed on two distinct crystallographic sites [6-8]. The crystal structure of the new ordered ammonium hydrogen succinate form is reported here and compared to that of the disordered one.

\section{EXPERIMENTAL}

\section{Synthesis of ammonium hydrogen succinate $\mathrm{NH}_{4} \mathrm{HC}_{4} \mathrm{H}_{4} \mathrm{O}_{4}$}

Single crystals of the new ordered form of ammonium hydrogen succinate, $\mathrm{NH}_{4} \mathrm{HC}_{4} \mathrm{H}_{4} \mathrm{O}_{4}$, were grown by slow evaporation of a water solution $(\mathrm{pH}=4)$ containing an equimolar mixture of ammonium thiosulfate $\left(\mathrm{NH}_{4}\right)_{2} \mathrm{~S}_{2} \mathrm{O}_{3}$ and succinic acid $\mathrm{C}_{4} \mathrm{H}_{6} \mathrm{O}_{4}$.

\section{Single-crystal X-rays diffraction}

The crystal structure measurement has been performed at room temperature $(\mathrm{T}=293 \mathrm{~K})$ on APEX II Bruker AXS diffractometer using Mo-K $\mathrm{K}_{\alpha} \mathrm{X}$-ray wavelength $(\lambda=0.71073 \AA)$ at the Centre de Diffractométrie X de l'Institut des Sciences Chimiques de Rennes. The measurement was processed with the APEX 2 program suite [19]. Frame integration and data reduction were carried out with the program SAINT [20]. The program SADABS [21] was employed for multiscan-type absorption corrections. The structure was solved by direct methods using the SIR97 
program [22], and then refined with full-matrix least-square methods based on $\mathrm{F}^{2}$ (SHELXL-2014) [23] through the WinGX platform [24]. All non-hydrogen atoms were refined with anisotropic atomic displacement parameters. Hydrogen were introduced in the structural model through Fourier difference maps analysis. Hydrogen atomic coordinates were refined, while equivalent isotropic displacement parameters were constrained to be equal to 1.2 times that of their parent atom. The higher residual electronic density peak is located between $\mathrm{C} 3$ and $\mathrm{C} 4$ atoms suggesting that no extra atom was missing. The conditions of data collection and structure refinement are summarized in Table 1. Atomic coordinates, site occupancy and equivalent isotropic displacement parameters at $293 \mathrm{~K}$ of the new ordered ammonium hydrogen succinate $\mathrm{NH}_{4} \mathrm{HC}_{4} \mathrm{H}_{4} \mathrm{O}_{4}$ form are gathered in Table 2.

Table 1. Summary of single crystal data collection and structure refinement conditions at room temperature of the title compound.

\begin{tabular}{|c|c|}
\hline Structural formula & $\mathrm{NH}_{4} \mathrm{HC}_{4} \mathrm{H}_{4} \mathrm{O}_{4}$ \\
\hline Space group & $P \overline{1}$ \\
\hline Temperature $(\mathrm{K})$ & $293(2)$ \\
\hline Formula weight $\left(\right.$ g. $\left.\mathrm{mol}^{-1}\right)$ & 135.12 \\
\hline Wavelength $(\AA)$ & 0.71073 \\
\hline Crystal system & Triclinic \\
\hline $\mathrm{a}(\AA)$ & $6.4868(16)$ \\
\hline $\mathrm{b}(\AA)$ & $7.4313(17)$ \\
\hline c $(\AA)$ & $7.4339(17)$ \\
\hline$\alpha\left(^{\circ}\right)$ & $112.058(8)$ \\
\hline$\beta\left(^{\circ}\right)$ & $96.477(9)$ \\
\hline$\gamma\left(\left(^{\circ}\right)\right.$ & $109.026(8)$ \\
\hline $\mathrm{V}\left(\AA^{3}\right)$ & $302.45(12)$ \\
\hline $\mathrm{Z}$ & 2 \\
\hline Calculated density $\left(\right.$ g.cm $\left.{ }^{-3}\right)$ & 1.484 \\
\hline Absorption coefficient $\left(\mathrm{mm}^{-1}\right)$ & 0.133 \\
\hline $\mathrm{F}(000)$ & 144 \\
\hline Crystal size $(\mathrm{mm})$ & $0.18 \times 0.06 \times 0.04$ \\
\hline Crystal color & Colorless \\
\hline Theta range $\left(^{\circ}\right)$ & $3.069-27.711$ \\
\hline h_min, h_max & $-8,8$ \\
\hline k_min, k_max & $-9,9$ \\
\hline 1_min, 1_max & $-6,9$ \\
\hline$\overline{\mathrm{R}}$ (int) & 0.0939 \\
\hline Reflections collected & 5436 \\
\hline Reflections unique $[\mathrm{I}>2 \sigma]$ & 876 \\
\hline Completeness & 0.981 \\
\hline Data/restraints/ parameters & $1398 / 0 / 110$ \\
\hline Goodness-of-fit & 1.014 \\
\hline Final $R_{1}[I>2 \sigma]$ & 0.0647 \\
\hline Final $w_{2}[I>2 \sigma]$ & 0.1613 \\
\hline Largest difference $\left(\mathrm{e} . \AA^{-3}\right)$ & 0.354 and -0.371 \\
\hline
\end{tabular}


Table 2. Atomic coordinates, site occupancy and equivalent isotropic displacement parameters at $293 \mathrm{~K}$ of the title compound.

\begin{tabular}{lllll}
\hline Atom & $\mathrm{x}$ & $\mathrm{y}$ & $\mathrm{z}$ & $\mathrm{U}(\mathrm{eq})$ \\
\hline C1 & $0.2972(4)$ & $0.8412(3)$ & $0.2016(3)$ & $0.0248(6)$ \\
C2 & $0.3204(4)$ & $0.6540(4)$ & $0.2245(4)$ & $0.0283(6)$ \\
C3 & $0.5612(4)$ & $0.6729(4)$ & $0.2785(4)$ & $0.0272(6)$ \\
C4 & $0.5879(4)$ & $0.4830(4)$ & $0.2918(3)$ & $0.0241(6)$ \\
N1 & $0.9375(4)$ & $0.1472(4)$ & $0.2469(4)$ & $0.0340(6)$ \\
O1 & $0.1035(3)$ & $0.8290(3)$ & $0.1472(3)$ & $0.0425(6)$ \\
O2 & $0.4750(3)$ & $1.0007(3)$ & $0.2380(3)$ & $0.0363(6)$ \\
O3 & $0.7610(3)$ & $0.4954(3)$ & $0.3863(3)$ & $0.0424(6)$ \\
O4 & $0.4113(3)$ & $0.3028(3)$ & $0.1902(3)$ & $0.0356(6)$ \\
H1 & $0.228(5)$ & $0.530(5)$ & $0.092(4)$ & 0.034 \\
H2 & $0.243(5)$ & $0.648(4)$ & $0.325(4)$ & 0.034 \\
H3 & $0.644(4)$ & $0.690(4)$ & $0.173(4)$ & 0.033 \\
H4 & $0.646(4)$ & $0.792(4)$ & $0.409(4)$ & 0.033 \\
H5 & $0.437(4)$ & $0.190(5)$ & $0.219(4)$ & 0.043 \\
H6 & $0.791(6)$ & $0.094(5)$ & $0.253(4)$ & 0.041 \\
H7 & $0.949(5)$ & $0.178(5)$ & $0.142(5)$ & 0.041 \\
H8 & $1.009(5)$ & $0.042(5)$ & $0.220(4)$ & 0.041 \\
H9 & $1.036(5)$ & $0.265(5)$ & $0.368(5)$ & 0.041 \\
\hline
\end{tabular}

\section{RESULTS AND DISCUSSION}

An ORTEP representation of the asymmetric unit with the atomic labels is shown in Figure 1. The main interatomic distances and bond angles are gathered in Table 3. The $\mathrm{C}-\mathrm{C}$ bond lengths are similar and coherent with values commonly measured in hydrogen succinate ions. The $\mathrm{C}-\mathrm{O}$ bond lengths of the two carboxylic groups are nonequivalent in agreement with the fact that only one carboxylic group is deprotonated. The shorter and longer C-O bond lengths, encountered on the protonated carboxylic group, are related to the carbonyl group (1.212(3) $\mathrm{A}$ ) and to the bond between carbonyl carbon atom and hydroxyl group (1.312(3) $\AA$ ). The C-O bond lengths encountered on the deprotonated carboxylic group are almost equivalents (1.239(3) $\AA$ and 1.267(3) $\AA$ ) and coherent with values usually found in deprotonated carboxyl groups. It could be noted that in the disordered form, the two carboxylic groups are equivalent with $\mathrm{C}$-O bond lengths of $\approx 1.28 \AA$ (corresponding to the bond between carbonyl carbon atom and hydroxyl group) and $\approx 1.24 \AA$ (corresponding to the carbonyl group) [7]. These values are in agreement with the statistical distribution of hydrogen atom on the two carboxylic group in the disordered form and with its ordering position in the ordered form. Finally, the hydrogen succinate molecule is in trans conformation in the ordered structural form and in gauche conformation in the disordered one. It leads for the ordered form, to high coplanarity of the atoms of the molecule (C1-C2-C3-C4 torsion angle of $-177^{\circ}$ ), where only the protonated carboxyl group is slightly twisted by a torsion angle of $23^{\circ}$ with respect to the carbon skeleton (Table 3).

Figure 1. Representation of the ammonium hydrogen succinate molecule $\mathrm{NH}_{4} \mathrm{HC}_{4} \mathrm{H}_{4} \mathrm{O}_{4}$. Displacement ellipsoids are shown at the $50 \%$ probability level. $\mathrm{H}$ atoms are represented as spheres of arbitrary radius.
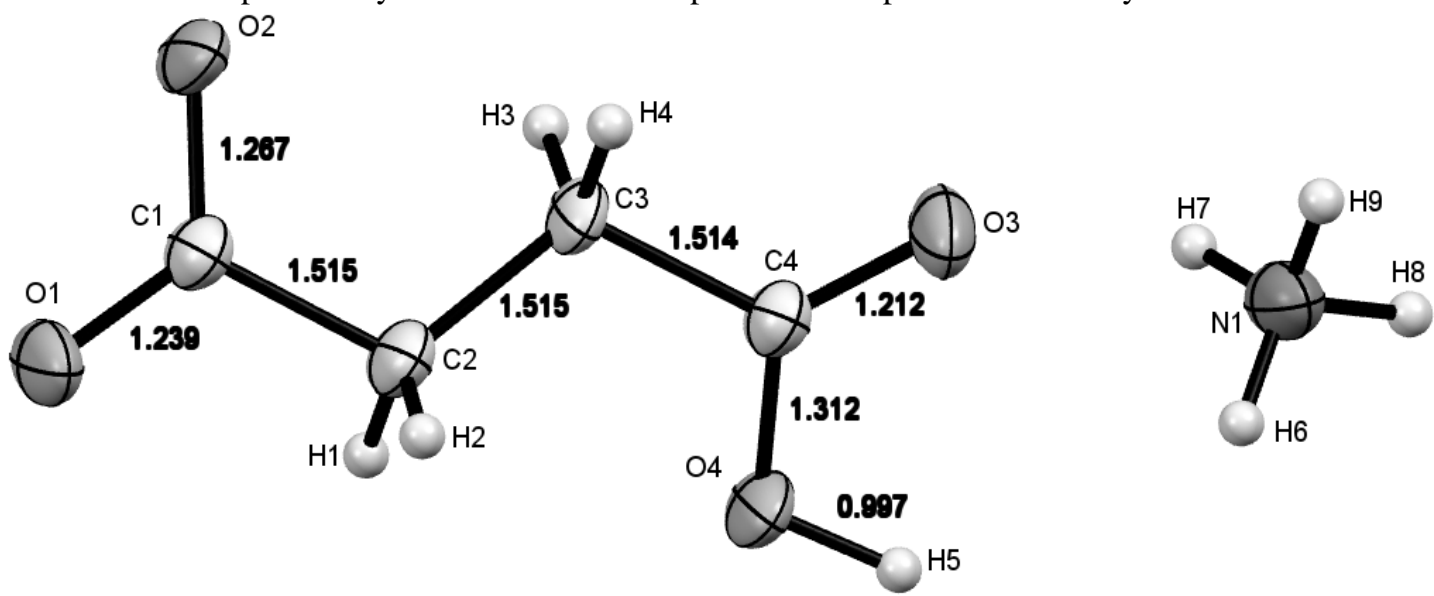
Table 3. Selected bond lengths $(\AA)$, bond angles $\left(^{\circ}\right)$ and torsion angles $\left(^{\circ}\right)$ at $293 \mathrm{~K}$.

\begin{tabular}{|c|c|c|c|c|c|}
\hline $\mathrm{C} 1-\mathrm{C} 2$ & $1.515(4)$ & $\mathrm{C} 1-\mathrm{C} 2-\mathrm{C} 3$ & $115(1)$ & $\mathrm{C} 1-\mathrm{C} 2-\mathrm{C} 3-\mathrm{C} 4$ & $-177(1)$ \\
\hline $\mathrm{C} 2-\mathrm{C} 3$ & $1.515(4)$ & $\mathrm{C} 2-\mathrm{C} 3-\mathrm{C} 4$ & $116(1)$ & $\mathrm{O} 1-\mathrm{C} 1-\mathrm{C} 2-\mathrm{C} 3$ & $176(1)$ \\
\hline $\mathrm{C} 3-\mathrm{C} 4$ & $1.514(5)$ & $\mathrm{O} 1-\mathrm{C} 1-\mathrm{O} 2$ & $124(1)$ & $\mathrm{O} 2-\mathrm{C} 1-\mathrm{C} 2-\mathrm{C} 3$ & $-4(1)$ \\
\hline C1-O1 & $1.239(3)$ & $\mathrm{O} 1-\mathrm{C} 1-\mathrm{C} 2$ & $118(1)$ & $\mathrm{C} 2-\mathrm{C} 3-\mathrm{C} 4-\mathrm{O} 3$ & $-158(1)$ \\
\hline $\mathrm{C} 1-\mathrm{O} 2$ & $1.267(3)$ & $\mathrm{O} 2-\mathrm{C} 1-\mathrm{C} 2$ & $119(1)$ & C2-C3-C4-O4 & $23(1)$ \\
\hline $\mathrm{C} 4-\mathrm{O} 3$ & $1.212(3)$ & $\mathrm{O} 3-\mathrm{C} 4-\mathrm{O} 4$ & $122(1)$ & & \\
\hline $\mathrm{C} 4-\mathrm{O} 4$ & $1.312(3)$ & $\mathrm{O} 3-\mathrm{C} 4-\mathrm{C} 3$ & $123(1)$ & & \\
\hline C2-H1 & $1.00(2)$ & $\mathrm{O} 4-\mathrm{C} 4-\mathrm{C} 3$ & $115(1)$ & & \\
\hline $\mathrm{C} 2-\mathrm{H}_{2}$ & $0.95(3)$ & C4-O4-H5 & $110(2)$ & & \\
\hline C3-H3 & $1.02(3)$ & H6-N1-H7 & $113(3)$ & & \\
\hline C3-H4 & $0.97(2)$ & H6-N1-H8 & $113(3)$ & & \\
\hline O4-H5 & $1.00(4)$ & H6-N1-H9 & $114(3)$ & & \\
\hline N1-H6 & $0.92(4)$ & H7-N1-H8 & $101(3)$ & & \\
\hline $\mathrm{N} 1-\mathrm{H} 7$ & $0.90(4)$ & H7-N1-H9 & $110(3)$ & & \\
\hline N1-H8 & $1.00(4)$ & H8-N1-H9 & $105(3)$ & & \\
\hline N1-H9 & $0.95(3)$ & & & & \\
\hline
\end{tabular}

Similarly to the disordered ammonium hydrogen succinate form [6], the crystal structure stability of the ordered form is ensured by electrostatic interactions between ammonium cations and deprotonated carboxyl groups but also by two kind of hydrogen bonds: $\mathrm{O}-\mathrm{H} \cdots \mathrm{O}$ and $\mathrm{N}-\mathrm{H} \cdots \mathrm{O}$. The $\mathrm{O} 4-\mathrm{H} 5 \cdots \mathrm{O} 2$ hydrogen bonds involve carboxyl groups coming from two different hydrogen succinate molecules (Table 4), leading to the formation of chains along the [010] direction (Figure 2). Ammonium interacts with four different hydrogen succinate molecules through the non-protonated oxygen atoms of the carboxyl groups (Figure 3), leading to the formation of four N$\mathrm{H} \cdots \mathrm{O}$ hydrogen bonds (Table 4). Hence, in the ordered form the structural stability is achieved by one O-H..O and four $\mathrm{N}-\mathrm{H} \cdots \mathrm{O}$ hydrogen bonds (Table 4), instead of two $\mathrm{O}-\mathrm{H} \cdots \mathrm{O}$ and five $\mathrm{N}-\mathrm{H} \cdots \mathrm{O}$ hydrogen bonds in the disordered form [7]. These different hydrogen bond networks are mainly explained by the different conformations of the hydrogen succinate molecules, trans in the ordered form and gauche in the disordered one, leading to different geometries of the molecule. In Figure 4 is shown a crystal structure representation along the $b$-axis of the ordered form highlighting the $\mathrm{N}-\mathrm{H} \cdots \mathrm{O}$ hydrogen bonds between ammonium molecules and hydrogen succinate chains. From this Figure, it could be noted that the carbon skeleton of the hydrogen succinate molecules and the shorter $\mathrm{N}-\mathrm{H} \cdots \mathrm{O}$ hydrogen bonds $(\mathrm{N} 1-\mathrm{H} 8 \cdots \mathrm{O} 1$ and $\mathrm{N} 1-\mathrm{H} 6 \cdots \mathrm{O} 2)$, as well as the $\mathrm{O} 4-\mathrm{H} 5 \cdots \mathrm{O} 2$ hydrogen bonds, lie

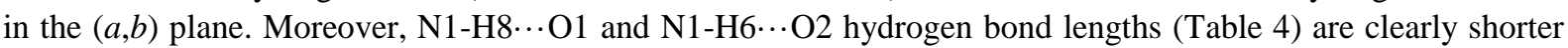

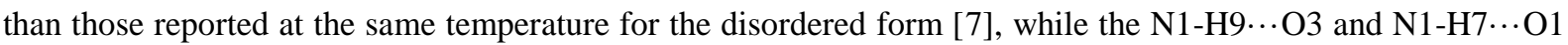
hydrogen bonds lying between the aforementioned planes (i.e. along the $c$-axis, Figure 4 ) have equivalent bond lengths. These results suggest that the crystal structure stability of the ordered form is mainly related to very short hydrogen bonds lying in the $(a, b)$ plane, which are favored by the high planarity of the hydrogen succinate molecule.

Table 4. Hydrogen bond geometries.

\begin{tabular}{lllll}
\hline $\mathrm{D}-\mathrm{H} \cdots \mathrm{A}$ & $\mathrm{D} \cdots \mathrm{A}(\AA)$ & $\mathrm{D}-\mathrm{H}(\AA)$ & $\mathrm{H} \cdots \mathrm{A}(\AA)$ & $\mathrm{D}-\mathrm{H} \cdots \mathrm{A}\left({ }^{\circ}\right)$ \\
\hline $\mathrm{O} 44^{\mathrm{a}}-\mathrm{H} 5 \cdots \mathrm{O} 2$ & $2.551(4)$ & $1.00(4)$ & $1.56(4)$ & $173(3)$ \\
$\mathrm{N} 1^{\mathrm{b}}-\mathrm{H} 7 \cdots \mathrm{O} 1$ & $2.988(4)$ & $0.90(4)$ & $2.12(4)$ & $164(3)$ \\
$\mathrm{N} 1{ }^{\mathrm{c}}-\mathrm{H} 8 \cdots \mathrm{O} 1$ & $2.797(4)$ & $1.00(4)$ & $1.80(4)$ & $173(3)$ \\
$\mathrm{N} 1{ }^{\mathrm{a}}-\mathrm{H} 6 \cdots \mathrm{O} 2$ & $2.822(3)$ & $0.92(4)$ & $1.91(4)$ & $171(3)$ \\
$\mathrm{N} 1{ }^{\mathrm{d}}-\mathrm{H} 9 \cdots \mathrm{O} 3$ & $2.878(3)$ & $0.95(3)$ & $1.93(2)$ & $179(3)$ \\
\hline
\end{tabular}

Symmetry codes: (a) x, $1+\mathrm{y}, \mathrm{z}$; (b) $1-\mathrm{x}, 1-\mathrm{y},-\mathrm{z}$; (c) $-1+\mathrm{x}, 1+\mathrm{y}, \mathrm{z}$; (d) 2 - x, $1-\mathrm{y}, 1-\mathrm{z}$. 
Figure 2. Crystal structure representation along the $a$-axis highlighting the molecular chains extending along the [010] direction through the existence of $\mathrm{O} 4-\mathrm{H} 5 \cdots \mathrm{O} 2$ hydrogen bonds. Ammonium cations are omitted for clarity.
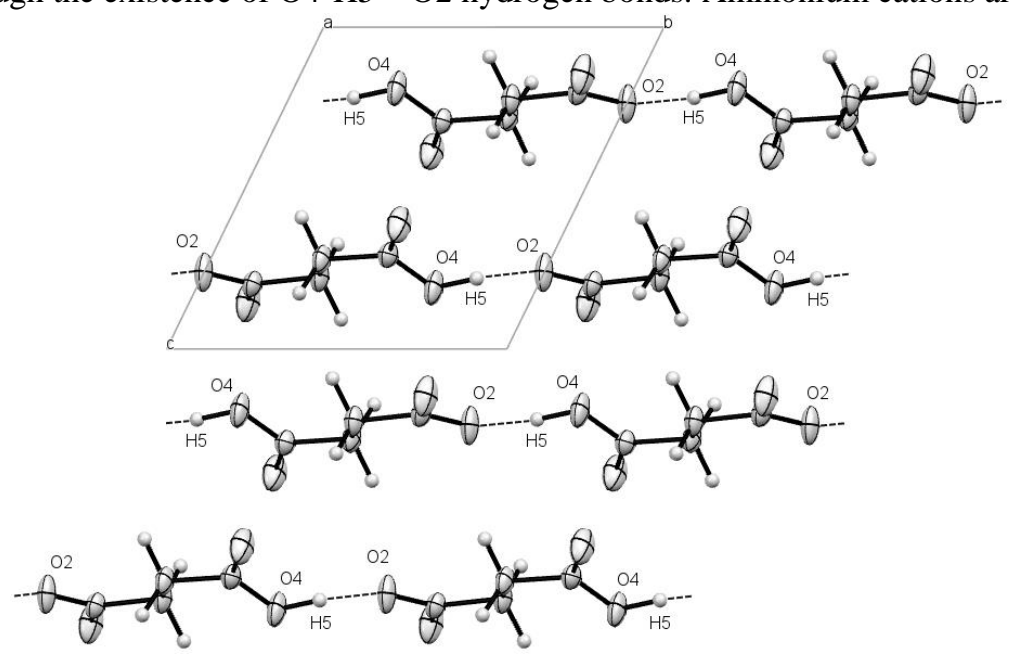

Figure 3. Representation of the N-H $\cdots \mathrm{O}$ hydrogen bonds.

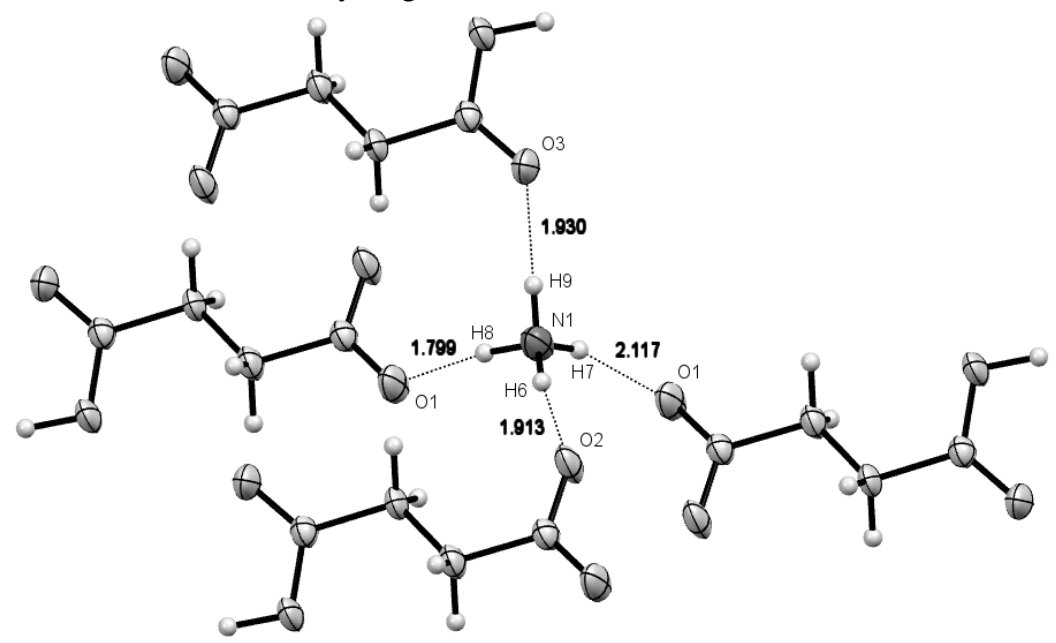

Figure 4. Crystal structure representation along the $b$-axis highlighting the $\mathrm{N}-\mathrm{H} \cdots \mathrm{O}$ hydrogen bonds between ammonium molecules and hydrogen succinate chains.

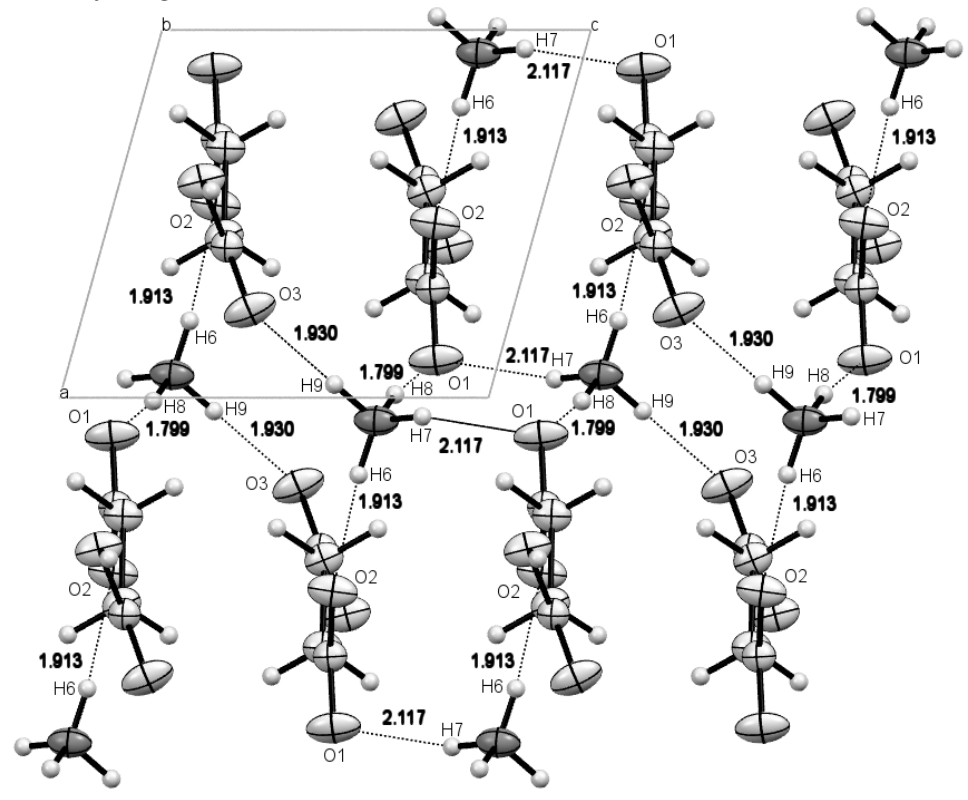


In conclusion, the crystal structure of a new ordered form of ammonium hydrogen succinate $\mathrm{NH}_{4} \mathrm{HC}_{4} \mathrm{H}_{4} \mathrm{O}_{4}$ compound was determined by single-crystal X-ray diffraction at room temperature. The results indicate that the hydrogen atom of the hydrogen succinate molecule is localized on one of the two carboxyl groups and that the molecule evidences a high planarity related to its trans conformation. The crystal structure stability is related to the existence of $\mathrm{O}-\mathrm{H} \cdots \mathrm{O}$ and $\mathrm{N}-\mathrm{H} \cdots \mathrm{O}$ hydrogen bonds, especially two $\mathrm{N}-\mathrm{H} \cdots \mathrm{O}$ hydrogen bonds particularly shorts in comparison to the disordered form and lying in the same plane than that of the carbon skeleton of the hydrogen succinate molecules. The existence of a structural transition at low temperature as observed for the disordered form was not examined.

\section{SUPPLEMENTARY MATERIAL}

The crystallographic data were deposited with the Cambridge Crystallographic Data Centre (CCDC 1866221).

\section{REFERENCES}

1. Kuppers H, (1982) Z Kristallogr 159:85-86

2. Kalsbeek N, (1992) Acta Cryst C 48:1389-1394

3. Mallison P R, Frampton C S, (1992) Acta Cryst C 48:1555-1556

4. McAdam A, Currie M, Speakman J C, (1971) J Chem Soc A 1994-1997

5. McAdam A, Speakman J C, (1971) J Chem Soc A 1997-1999

6. Haussühl S, Schreuer J, (1993) Z Kristallogr 206:255-265

7. Hirano A, Kubozono Y, Maeda H, Ishida H, Kashino S, (1996) Acta Cryst B 52:323-327

8. Kashino S, Taka J, Yoshida T, Kubozono Y, Ishida H, Maeda H, (1998) Acta Cryst B 54:889-894

9. Schreuer J, Münch T, (1994) Z Kristallogr 209:32-35

10. Kalsbeek N, Larsen S, (1991) Acta Cryst C 47:1005-1009

11. Kalsbeek N, (1991) Acta Cryst C 47:1649-1653

12. Dziuk B, Zarychta B, Ejsmont K, (2014) Acta Cryst E 70:917-918

13. Padmavathy R, Karthikeyan N, Sathya D, Jagan R, Mohan Kumar R, Sivakumar K, (2016) RSC Adv 6:6846868484

14. Khorasani S, Fernandes M A, (2012) Acta Cryst E 68:1204

15. Parvez M, Dalrymple S, Cote A, (2001) Acta Cryst E 57:163-165

16. Fundamensky V S, Kochina T A, Kondratenko Y A, Zolotarev A A, Vlasov Y G, Ignatyev I S, (2017) J Mol Liq 230:113-120

17. Loginov S V, Dain I A, Rybakov V B, Ofitserov E N, Gordeev D A, Storozhenko P A, (2018) Crystallography Reports 63:58-64

18. Guo J, Tolstoy P M, Koeppe B, Denisov G S, Limbach H H, (2011) J Phys Chem A 115:9828-9836

19. APEX 2 program suite V2014.11-0, Bruker AXS Inc., Wisconsin, USA

20. Sheldrick G M, (2013) SAINT version 8.37A, Bruker AXS Inc., Wisconsin, USA

21. Sheldrick G M, SADABS version 2014/5, Bruker AXS Inc., Madison, Wisconsin, USA

22. Altomare A, Burla M C, Camalli M, Cascarano G L, Giacovazzo C, Guagliardi A, Moliterni A G G, Polidorib G, Spagnac R, (1999) J Appl Crystallogr 32:115-119

23. Sheldrick G M, (2015) Acta Crystallogr, Sect C: Struct Chem 71:3-8

24. Farrugia L J, (2012) J Appl Crystallogr 45:849-854 